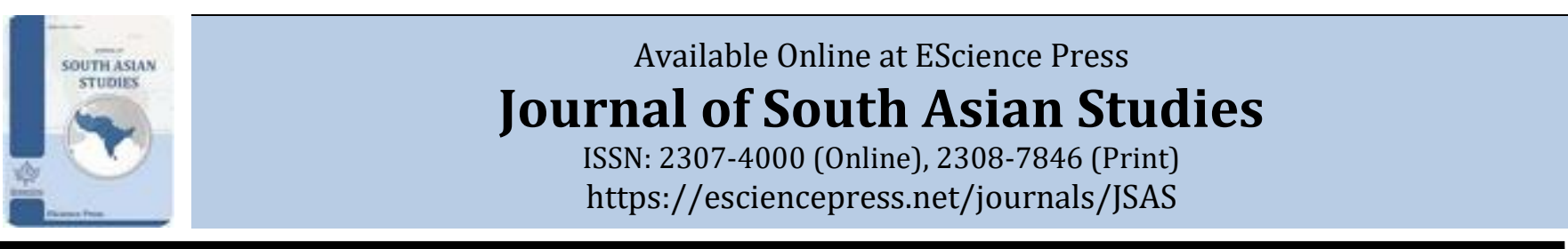

\title{
Social Construction of Extremism: Case Study of South Punjab
}

aSidra Jamil*, aNaeem Ahmed, bSibghat Ullah Bajwa, cNazar Hussain

a Department of International Relations, University of Karachi, Pakistan.

b Department of International Relations, National University of Modern Languages (NUML), Islamabad, Pakistan.

c The Times Institute, Multan, Pakistan.

*Corresponding Author Email ID: sidra.bajwa@outlook.com

\section{A B S T R A C T}

South Punjab, the land of Sufi saints, and epitome of peace and love has transformed into the fulcra of militancy in last two decades. The current study draws the connection between society (social-organization) and social interaction with the construction of individual's perceptions and behavior. The study also underscores the flaws lie in the social composition of society of South Punjab that contributes to the construction of violent perceptions and behaviors, and trigger individuals to join militant wings. The research was conducted in Multan region. The qualitative methods: ethnographic observation and semi-structured interviews are used in this research. Purpose sampling is used to select sample population encompassing people from diverse social backgrounds. The findings of the research unfold that prime social institutions including religion, education, economic and government are mal-functioning, due to which region became heartland of militancy.

Keywords: Society, Social Interaction, Militancy, South Punjab.

\section{INTRODUCTION}

With the catastrophe of September 11, terrorism has not only gained attention of international community as a political threat but also laid foundations to study the very phenomenon through different lenses at academic level. Since then, just like other parts of the world, umpteen researches have been conducted in Pakistan unfolding the political facts (including use of religion for political gains) and realities associated to the emergence and prevalence of intense wave of terrorism in the country. Unfortunately, in Pakistan, no significant effort has been made to study terrorism through the spectacles of sociology or psychology, consequently, use of force became the only effective mean to get the country rid of terrorism. Robust efforts of peace may have managed the issue for time being but were unable to bring enduring peace, therefore, terrorism always re-erupted in Pakistan once the fire was ceased. It is crucial to study the social factors contributing to gendering motivation among the individuals to acquire membership of various militant and terrorist wings. Human personality is the result of social interaction. An individual's perceptions evolved when he/she interacts within a social organisation or society comprises of numerous social institutions (Oakley, 1972). These socially engendered perceptions found the behaviours followed by actions; hence it can be said that actions are the reflection of a society because an individual acts according to the social expectations and sanctions. A stable social-organisation or society has its all the basic social institutions working in parallel to each other. Primary social institutions: family, education, religion, economy and government must deliver their very purpose to the society. Each of the mentioned above social institution has specific yet crucial role in the personality building of an individual's personality. This paper examines as to how social interaction of an individual with various social institutions nurtured the personality prone to militancy and terrorism. Due to limited financial resources and time, this paper is focused on the district of Multan situated in Southern part of Punjab province- commonly known as South Punjab. 


\section{South Punjab: The Fulcra of Militancy}

Punjab, the land of five rivers, ranks Pakistan's second largest province by area and first in terms of population (Provincial Summary Results of 6th Population and Housing Census-2017, 2017). The province is bearing the brunt of militancy for more than two decades. Taliban hired a large number of recruits from the province during the US-Afghan war. The hired recruits of Taliban were first used to be called as 'Punjabi Taliban' based on their Punjabi vernacular that distinguish them from other membership of the organisation (Yousafzai, 2016). According to Observer Research Foundation, 3000 to 8000 terrorists from South Punjab were fighting against United States in parallel to their Afghan counterparts in Afghanistan in 2010 (John, 2010). The South Punjab (Southern part of the Punjab province) is considered as the safe-haven for Punjab based militant outfits (Pakistan's Jihadist Heartland: Southern Punjab, 2016). Southern Punjab includes the districts of Multan, Muzaffargarh, Lodhran, Vehari, Khanewal, Sahiwal, Pakpattan, Bahawalnagar, Bahawalpur, Rahimyar Khan, Layyah and Dera Ghazi Khan as well as Jhang, on the cusp of southern and central Punjab (Zia, 2012). All the above mentioned districts collectively cover the area of more than 99,572 square kilometres that makes the 48.5 percent of the Punjab province. South Punjab, approximately half of the Punjab's area is home to 29.74 million people (Klasra, 2016). The region of South Punjab shares its western border with Federally Administered Tribal Area (FATA) and Eastern border with neighbouring India (Pakistan: The Militant Jihadi Challenge, 2009). Afghanistan and India are engaged in escalation of militancy and terrorism in Pakistan (RAW \& Afghan Intelligence Agencies involved in terrorist activities in Pakistan: Analysts, 2018). Pakistan Military Intelligence has also caught Indian Research and Analysis Wing (RAW) trained militants from South Punjab (Awan, 2016). FATA is located on the porous Pak- Afghan border that facilitates the terrorist to cross border during government operations, whereas adjoining Indian land benefits the outfits in conducting anti-Pakistan ventures.

South Punjab based Punjabi Taliban shuttle across the country to provide logistic support to Afghanistan and Pakistan based terrorists to carryout terror ventures in Pakistan (Abbas, 2009). Between March 2005 and March 2007 alone, for example, about 2,000 militants from southern and northern Punjab Province reportedly moved to South Waziristan and started different businesses in an effort to create logistical support networks (Latif, 2009). Moreover, mostly terrorist mentioned in the wanted list in 'Red Book' of Punjab Police are native of South Punjab (Red Book, 2018). The region of South Punjab is base of four militant organizations: Lashkar-i-Jhangvi (LeJ) has less than a thousand active militants (Abbas, 2009); Sipah-i-Sahaba Pakistan (SSP) have almost a hundred thousand followers but active fighters range in between 2000 to 3000 (Abbas, 2009); Jaysh-i-Muhammad (JeM) has a membership of 5000 and about 1500 to 2000 are active fighters (Abbas, 2009); Sipah-e- Mohammad Pakistan (SMP) has a cadre base of 30000 Shiites (South Asia Terrorism Portal, 2014). LeJ, SSP, and JEM belongs to Sunni school of thought, whereas SMP is the follower of Shiites school of thought. Therefore, parallel to violent extremism, militancy and terrorism, sectarian schism is also a prominent phenomenon in South Punjab (Khalti, 2015).

In 2016, Pakistani government has launched grand operation against terrorists (Rao, 2017); where more than 11000 intelligence-based operations were carried out in Punjab (Mahmood, 2017). According to Major Taj Muhammad, the Inter Services Public Relations (ISPR) Director for South Punjab, forty-nine militants were detained in operation in South Punjab in 2016 (Qarni \& Ismaeel, 2016). According to Deputy Inspector General (DIG) Operations Punjab Police, Dr Haider Ashraf, 'In same year seven thousand people were arrested by police after interrogation (Qarni \& Ismaeel, 2016).' Despite of all the robust effort, Punjab province is under the continuous threat of militancy (Dawn, 2018). Use of force may manage the problem of militancy and terrorism temporarily but cannot bring about sustainable peace and security unless de-radicalisation of militants is done at the grassroots level. For this, it is crucial to identify the social forces and influences prevailing in South Punjab that are contributing to the gendering of militants and terrorists. Cure is almost impossible without knowing the cause of the problem. The later part of the study unfolds the social influences that encourage the native population to seek membership of terrorist groups.

\section{Research Questions}

- How does social interaction within a socialorganisation or society influence to shape 
perception, behaviour and actions of an individual?

- How is social interaction within the socialorganisation of South Punjab leading individuals

\section{Objectives of the Study} towards militancy and terrorism?

The objectives of present research are as follows:

- To develop an in-depth understanding on socialorganization of South Punjab;

- To draw relationship between social-organization and individual's perceptions, behaviors and actions;

- To understand the impact of social forces on perception, behaviour and actions of the natives of South Punjab.

\section{Significance of the Study}

Number of researches have been conducted on militancy in Pakistan that discusses the terrorism as a political issue (including use of religion for political gains), but no significant research has tried to reveal the social influences that lead an individual to aspire vocation as a militant or a terrorist. In addition to that region of South Punjab is neglected by research scholars, therefore primary researches on South Punjab are very rare. In this regard, the present study not only gives the in-depth picture of social-organization of South Punjab but also tells that how social interaction of individuals within that social-organization construct their rigid mindset followed by aggressive behavior that reflects in their actions, and eventually transform them into militants.

\section{RESEARCH METHODOLOGY}

\section{Nature of the Research}

The present research is ethnographic in nature. Ethnographic study is a method used in qualitative research in which a researcher makes observation and develop interaction with population under study in their real environment (Institutional Review Boaard for Social and Behavioral Science, 2012). Researcher lived and interacted with people in Multan region for two months.

\section{Development of the Instrument}

Due to unavailability of sufficient resources and opportunity, the researcher has not presented the research topic in any seminar or conference. Therefore, ten expert individuals from the fields of sociology, psychology, counter violent-extremism and counterterrorism were invited to discuss the research areas, and to identify and discourse the research variables. Experts were briefed on topic, scope, nature, research questions, objectives and significance of the research through detailed presentation by the researcher. In that meeting, research instrument i.e., semi-structured interviews were selected by keeping in view the demands of the study. Afterwards, interview guide was prepared. Prepared interview guide was the primary tool in the current research and was prepared in the light of already available literature on the subject matter ( Edwards \& Holland, 2013). For face validity, prepared interview guide was distributed to the experts (members present in the initial meeting). Later, interview guide was further refined and improved in the light of valuable suggestions from experts. Subsequently, interview guide was translated into native language i.e. Urdu to maximise the degree of comprehension between the interviewer and the interviewee, and to maintain the real meanings of language used in the actual interview guide. Translated version of interview guide was reviewed by a language expert for the correction of any error and to improve the language quality. The interview technique adopted by the researcher was aimed to have shebang on every aspect that falls under the scope of current research (Boyce\& Neale, 2006). In parallel to semi-structured interviews, participant observation method was also adopted to have deep insight of the social organisation of the South Punjab. This method is adopted when in-depth understanding is required to unfold the intricate socialorganisation (Emerson, Fretz, \& Shaw, 2001), therefore chose to study the South Punjab.

\section{Pilot Study}

Before the start of field research, a pilot study was conducted. The pilot study comprised of interviews of eight interviewees: easily available residents of South Punjab. The core purpose of pilot testing was to remove all the irrelevancies present in the interview guide and to make interview guide more comprehensive and comprehensible for the ease of sample population. The interviewees selected for pilot testing were exempted from the later field research.

\section{Sampling}

Purpose sampling was used in this research. Purpose sampling is the technique of non-probability sampling that comprises of contributor assortment grounded on the characteristics of sample population that is relevant to the research (Thornhill, E.T. Lewis, \& Nk Saun, 2007, p. 288). The participants volunteered in research were from diverse social background including sects, educational backgrounds and career pathways. Due to 
sensitivity of the topic, all the participants selected for this research were adults i.e. each one of them was above eighteen years of age. The researcher conducted thirty-five semi-structured interviews of individuals from versatile social background. The interviewees were molvis (religious clerics), police officers, students, academicians, agriculturist, political representatives, etc.

\section{Data Gathering}

The research was carried out in the region of South Punjab. In order to develop an in-depth know-how of social-organisation of the region, ethnographic study has been carried out. During the period of research, the researcher has not only socialised with the native people on daily basis but being a native of Punjab has also participated in the social gathering (funerals, marriage and birth celebrations) and recreational activities such as Folk Melas (funfairs) and Urs (celebrations on the death anniversary of Sufi saints in South Asia, usually held at the shrine of Sufis). In-depth interviews were carried out to acquire a detailed understanding of perceptions, behaviours and actions of people viz-a-viz social-organisation of South Punjab. Small research sample is selected to attain wide-ranging information on the research topic. While carrying out the interviews, interviewees were considered as well-informed source, whereas researcher as an unfamiliar person.

\section{Procedure}

Prior to interview, the researcher tried to establish rapport with the interviewee. Rapport was important to build level of understanding, trust and comfort between the researcher and the interviewee, moreover it also helped to minimise the ambiguities lying in the participant's mind (Ryan \& Dundon, 2008). To maximise the level of comfort, sometime researcher had also communicated to local participants in vernaculars such as Punjabi and Saraiki language. Subsequently, informed consent was granted from the participants in both verbal and written form. The consent form contained the objectives of the research, surety to maintain confidentiality of participants' identity and responses, and respondents' right to withdraw from at any point of the current study. Next to signing consent, respondents were asked for their demographic in detail. Due to the sensitivity of the topic and comfort of the respondents, audio-video recordings during interviews were avoided. Field jottings were done during the interview processes, and were transcribed into field notes, later. To maintain the flow of interview, a research assistant was hired for verbatim transcription. Usually, participants were visited at their home or work places in accordance to their availability, comfortability and personal concerns.

\section{Data Analysis}

After the completion of fieldwork, technique of thematic analysis is used to analyse the replies of the respondents. Thematic analysis is a type of analysis used in in qualitative research that focus on the identification and categorization of themes within the data based on coding and labelling (Braun \& Victoria, 2006). The current research is categorized into four sections based on a separate theme analysis. For analysis, transcribed verbatim in Urdu were translated into English language, and were proofread by a language expert (holding an M. Phil in English linguistics) to remove any errors in translated interviews.

\section{Limitations}

Consequent of ongoing counter-terrorism operation in South Punjab, natives of Multan are observed cautious in expressing their thoughts and hesitant in sharing information. Due to sensitivity of the research topic, the researcher has not acquired the diverse perspectives as expected. Due to religious and cultural norm of Purdah (the norm in Muslim societies to screen women from stranger men), the researcher being a female was not allowed to walk around in mosques and seminaries freely to document the diverse perspectives. Another significant concern posed was about the Punjabi nativity of the researcher that could have affected the quality of the research and might cause the chances of biasness in the analysis of the gathered data, therefore the researcher tried to overcome the chances of biasness through adopting the process of self-reflectivity (Primeau, 2003).

\section{Ethical Consideration}

The researcher followed the research ethics strictly. Privacy of the research participants is held secret by considering the elements that may cause threat to their secrecy. The researcher clearly briefed the objectives of the present research to the respondents. In addition to that participants were also told about their right to withdraw from research anytime during the investigation, if the present research made them 
uncomfortable in any way. Written and verbal permission was sought from every participant. The researcher had pseudo named the respondents during the fieldwork to guarantee the anonymity of the participants. To maintain the quality of the research, the researcher avoided at maximum to reveal personal sentiments and opinion in front of the responders to document the actual positions and responses of the participants in order to eradicate the chances of any biasness or discrimination. Approval was granted by the participants, and their physical and emotive security and wellbeing was surefire during the fieldwork.

\section{Area Profile}

The locale of the present research is Multan; a district of South Punjab. Multan ranks the seventh in population in Pakistan (Population of Major Cities Census - 2017, 2018) and is considered as an epitome of cultural diversity. The total area of the city is 3721 square kilometers, and population is five million (City District Government, Multan , 2018). The city is home of world's oldest civilization called Indus Valley Civilization and is inhabited as a minimum of five thousand years (Khan, 1983). According to Hindu mythology, Multan was settled by the tribe called 'Mul,' whereas according to the Persian Historian Frishta, the city was settled by great grandson of prophet Noah (Calcutta Review: Volume 9293, 1891). Multan is also called the city of saints, therefore, shrines of various prominent Sufi saints including mausoleum of Shah Yousaf Gardezi, Mai Maharban, Bahauddin Zikarya, Shah Rukne Alam, Khawaja Awais Kagha, Syed Musa Pak, Hafiz Muhammad Jamal Multani are found in the city. A saint is usually considered as wali (friend of God), shafi (someone who strengthen the bond between God and the man), and auliya (favored by God) (Currie, 2006). Sufis are spiritually pure and assigned with the divine duty to transform the society on religious teaching in order to create social solidarity and stability. Sufis transit devotion in people to live their lives on religious principles to ensure social peace and harmony (Currie, 2006, p. 99). Sufis propagated the message of peace and harmony and directed their disciples to do good and act decent to their enemies also (Nizami, 2007, p. 99). Khanqahs were the monasteries build by the Sufis where people from distant regions used to join and visit to seek knowledge from them. Every khanqah had a library associated with it. After the death of saints, their shrines were constructed adjacent to khanqahs, these shrines are called dargahs (Currie, 2006, p. 02).

Eventually khanqahs along with their very purpose lost under the dust of history and dargahs became the center of religious and social gatherings. With passage of time, Sufi culture was replaced by Pir culture. Pir is a perceived spiritual guide (Newby, 2013), and custodian of dargah. Mostly pirs are feudal and own large areas of land. Parallel to Pirs, Molvis (also called Mullah and Maulana) are also given special social positions in South Punjab. Molvi is an honorific religious title given to highly qualified religious scholar who completed studies in a Madrassa (Islamic school or religious seminary). Molvi is also an Imam Masjid (custodian of Mosque). There are more than 15,000 madrassas working in Punjab, and 2400 of them are located in South Punjab (The Nation, 2016); whereas 1100 of them can be seen in district Multan only (Saleem, 2010). Wafaqul Madaris Al-Arbia is the Punjab's biggest madrassa located in Garden Town Multan; it runs 21,633 seminaries across Pakistan. The madrassa housed and feed 1.4 million male and 0.7 million female students across the country (The Nation, 2016). Other than religious education, Multan has number of public and private educational institutions including schools, colleges, medical colleges and universities.

Multan, despite being hub of religious institutions and Sufi Islam, has been facing the problem of militancy and terrorism since the upheaval of 9/11. In 2004, a car bombing took place in Multan that killed forty people and almost a hundred injured (BBC, 2006). In 2015, Baluchistan Liberation Army (BLA), a banned terrorist group launched an attack on bus station in Multan that killed ten people and sixty were injured (The Nation, 2015). Pakistani government has taken robust measures such as police operations to curtail militancy in the district. The district is providing hide-outs to the militants. In December 2014, four militants involved in plotting Chehlum (Shiite rally) attack were killed by police (Pakistan Today, 2014).

In 2016, eight Al-Qaida militants were killed in Multan (Gabol, 2016). These militants were planning to attack Multan University (News Media Live, 2016). In February 2017, six militants were killed in Multan in a raid by Counter-Terrorism Department (CTD) of Punjab Police (The Express Tribune, 2017). In June 2017, CTD foiled a terrorist attack and detained three suspected (Qarni, The Express Tribune, 2017). On September 30, 2017, 
terror bid foiled and four alleged terrorists were caught by CTD (Geo News, 2017). Same year in the month of October two more militants were killed in CTD operation (Dunya News, 2017). Two days prior to Christmas in December 2017, plotting of Christmas terror attack was foiled, and three terrorists were held captive (Pakistan Observer, 2017). On March 09, 2018, CTD arrested a terrorist and seized a cache of weapons in Multan (Pakistan Today, 2018). On 24th of same month, four terrorists were caught with arms and explosives in Multan (The Nation, 2018). In June 2018, two more militants were arrested during an operation in Multan (Radio Pakistan, 2018).

Mentioned above are the few incidents of terrorism and counter-terrorism that truly depict the situation of the district of Multan. Even with launch of effective counterterrorism strategy by the government, terrorists are still found plotting and executing of terror ventures in the city. Hence, it is of paramount importance to study the social forces and influences motivating the individuals of Multan district towards terrorism.

\section{INDIVIDUAL, SOCIAL INTERACTION AND BEHAVIOUR}

Perceptions, behaviors and actions are not by birth, but humans learn them through the process of social interaction (Goldthorpe, 2007). Observation is the first step towards the learning process. In early years of life, an individual observes and tries to copy the actions of people and events he encounters. Language is the first outcome of that social interaction, followed by every action he commits afterwards. In other words, one can say that an individual acts according to his environment. One's social-setting nurtures the aspects of one's life. Social interactions generate experiences that leave impressions and helps to gender personality of an individual according to social apparatus. Therefore, an individual from a particular society or socialorganization behaves in a particular manner that differentiates him from people coming from other societies. For example, an individual coming from an exclusive and xenophobic society will have a rigid and intolerant mindset that would also reflect is his actions; whereas a person coming inclusive society will behave in a tolerant and accommodative way.

A society refers to a social-organization where groups of people live in a shared social territory and builds persistent social interactions (Giddens, 1991). A society or social-organization is comprised of various social institutions. Social institutions are imperative structural components of a society that performs specific functions and discourse fundamental activity or set of activities within a society (Ball, 2001). It is impossible for a society to stay extant without social institutions. Numerous social institutions exist in a society that contribute myriad definite role in facilitating the social life of individuals. The key social institutions include family, religion, economy, education, and government. A social institution cannot work independently but is dependent upon other social institutions for the deliverance of its respective purpose (Joas \& Knöbl, 2010).

Social institutions all together form a social arrangement that constructs behaviors and relationship patterns that are compactly entwined and enduring and performs all the functions of a society (Giddens, Sociology, 2009). Due to their normative character, social institutions order and structure the perceptions and behaviors of membership of a society (Parsons, 1952). They regulate the behaviors of membership of a society in fundamental social domains: family as a social institution is responsible for reproduction and socialization; education in both of its formal and informal modes, transmits knowledge and skills; economy is responsible for production and supply of goods and services; government as an institution maintains the social order; religion brings social control and solidarity in a society (Goldthorpe, 2007).

A social institution has ability to contribute various functions at same and/or over time. For example, religion besides delivering its basic task of peace and harmony, also directs on political and economic affairs of the society. For social stability, it is crucial for social institutions to work in parallel with each other. If a social institution fails to deliver its specific role, or overshadow the role of other institutions, social disorganization occurs that brings about social instability and deviance (Barnard, 2000). Membership of a society interacts within the social institutions continuously, therefore deviance or instability in social structures pose direct impact on them. According to Okley, 'an individual builds the basic concepts that how he "must" feel, think, behave and act according to social expectations and sanction (Oakley, 1972).' Social sanctions and expectations are ordered and structured by social institutions, for example, in traditional social-organization like Saudi 
Arabia, society allows men to be in multiple marriages at same time, whereas in modern social-organization like United States, men are not allowed to have two wives at a time. When an institution fails to deliver its role, or dominate the roles of other institutions, it reflects in the thoughts and behaviors of individuals as well. It is commonly observed that if economy as a social institution fails to maintain just distribution of wealth in society, crime rate increases as a result of inflation and poverty. Similarly, if religion overlaps the role of other institutions and politicized afterwards, charity (a social obligation) transforms into funding of inhumane activities.

\section{FINDINGS AND DISCUSSION}

From the preceding discussion, it is deduced that life experience and social interaction within a socialorganization or society internalized the thinking and behavior patterns in human beings. It is crucial to determine the factors affecting the social stability in South Punjab; how failure of social institution, or domination of social institutions over each other disorganize the social structure of the society of Southern Punjab, and how social interaction within disorganized social structures is leading individuals towards crimes, militancy and terrorism. The proceeding discussion is categorized into different themes unfolding the nature and roles of social institutions in the social construction of militancy in South Punjab.

\section{Religion}

As a social institution, religion is liable for social control and social solidarity. Its function is to regulate religious sentiments, rituals and beliefs and practices, and to promote and preserve them (Parsons, 1952). Religion has vital impact on human society as it constructs the societal viewpoint of an individual. It profound influence on individual's behavior by revealing on him divine doctrines, as well as worldly and hereafter rewards and punishments. Because religion directly influences a person's emotions and sentiments, therefore membership of a society can easily be motivated to perform any act under the canopy of religion. This act can be positive or negative in its very nature. The impact of religion on the South Punjab society is greater than any other region of the country. South Punjab is under the influence of Islam for centuries, and the region has made significant contributions in propagation and promotion of Islam not only in South Asia, but in the world at large. Sufis were preeminent religious scholars and thinkers with high command on Islamic teachings and laws. With time, Sufi culture have disappeared, and role of Sufis transmitted to maulvis (certified Islamic scholar).

In South Punjab, every mosque and religious seminary is owned by a maulvi. In Punjab province 1.5 million student are enrolled in religious seminaries, and seventy percent of them are enrolled in South Punjab (Saleem, 2010). Seminaries of South Punjab are always in spotlight for their role in breeding violent extremism, militancy and terrorism. According to Rehman Malik, the former Interior Minister of Pakistan, 'governments have list of 1764 terrorist with their record available and 726 of them are natives of South Punjab (Saleem, 2010). Religious institutions also receive funding from outside the Pakistan to carry out streamline flow of their activities. During field study, the researcher found out that with few exceptions, all maulvis fail to meet the basic criteria of being labelled as a maulvi or mullah. A maulvi or mullah is someone who is formally graduate from a religious institution and has in-depth knowledge of Sharia (Islamic teachings and law). Most of the socalled maulvis found in religious institutions were not maulvis but hafiz (someone who learnt Quran by heart in Arabic language) and Qari (someone fluent in reciting Quran according to rules of recitation). These Hafiz and Qari were unknown of the meanings of Quranic verses they recite. In South Punjab, religious instrumentalism is found at peak and Islam is used a tool to indoctrinate the extremist ideologies in students enrolled in seminaries. A certified expert of Sharia based in a local seminary in Multan said:

Being a Dai (propagator of Allah message), I consider Da'wah (Message of Islam) a great responsibility. Unfortunately, in this region, mostly people sitting in mosques and seminaries do not have credentials for sitting as an Imam Masjid (Islamic prayer leader), in fact they do not know the $A B C$ of religion Islam. Religion for them is not a sacred duty, but solely a business.'

Similarly, a professor of Islamic Studies stated: 'Some illiterates are defaming religious scholars. These so-called clerics claim themselves to be followers of prophet Muhammad (PBUH), however, they are not at all following the teachings of Islam. Islam is a religion of peace. 
Holy Prophet (PBUH) is epitome of kindness for entire humanity. Muhammad (PBUH) was someone who always invocated felicity for his abusers. Who among these so-called custodians of Islam, you find following the footsteps of Muhammad (PBUH)? No one!'

A person serving as an Imam (someone who leads prayers in mosques and other religious gatherings) of local mosque revealed his religious credentials by stating,

'I am neither a hafiz nor formally studied religion in any Islamic school or seminary. I came as a Moazan (the one who gives the call to prayer), and eventually became Imam of this mosque. Now I direct people towards the path of Allah.' Islam clearly and strictly forbids the use of illegal means to pursue any religious or social cause, including waging Jihad. The Tehreek-e-Taliban's (TTP) financiers detained from Karachi divulged that they have fatwa (religious decree) which says ransom money to fund Jihad is justified (Bin Perwaiz, 2008). Another financier of TTP said that drug trade to facilitate cause of Jihad is not forbidden: the profit crop is Allah's blessing to contest against infidels (Shah, 2008). Moreover, South Punjab portrays the complex 3-dimensional image of alliance between terrorism, organized crime and corruption (Winterbotham, 2016). During field research, the researcher was told that in South Punjab, it is common practice to give ten percent of the cash crop to the maulvi of local mosque and seminary. Seminaries also raise Zakat (charity) in the month of Ramadan (the month of fasting) and collect animal hides on Eid-ulAzha (the day to celebrate the sacrifice of Prophet Abraham). It is a famous proverb in South Punjab, 'sacrifice is for Allah, and hide is for the maulvi.' Kidnappings for ransom, and looting are additional means to generate income for these so-called religious activities. A student of Sharia law currently enrolled in Islamabad based university and native of Multan region unfolds the religious politicization and caliber of pseudo clerics by saying,

'Religion is tremendously politicized in our South Punjab. After doing extensive and in-depth study of Quran and Sunnah (life of holy prophet), I realized that the debates and arguments made by pseudo clerics on Friday and Eid sermons are open exploitation and open violation of religious teachings. Unfortunately, pseudo molvis are using religion for their own good, hence defaming Islam and true religious scholars'

According to the report of International Crisis group, crime and terrorism are intact phenomena in South Punjab (Pakistan's Jihadist Heartland: Southern Punjab, 2016). The Criminal-Terrorist nexus in Pakistan has different dynamics from religious terrorism. Terrorists are structurally linked with criminal wings and coteries. Terrorists share their organizational expertise and trade arms with black money of criminals (Hussain, 2012). A Station House Officer (SHO) of local police station drew the connection between terrorists and criminals by saying,

'They are criminals in the day light, and terrorist in the murkiness of night.'

He further added,

'Terrorists have developed nexus with criminals. They rob banks and steal automobiles to fulfil their economic needs.'

A local shopkeeper engaged in the business of spare parts of automobiles said,

'They steal automobiles and ends in opening them into parts, and later sale them as spare parts in the market.'

Pseudo clerics found in seminaries and mosques of Multan region are hardcore in their positions. Though they have no religious credentials, yet the society has embraced them as religious authorities and follow them blindly. People are petrified to argue with them or pose any question before them. If a person muster courage to pose question before a cleric, there are significant chances that he may be accused of committing blasphemy. A tanga (carriage) rider told while endorsing the religious authority of clerics,

'There is no concept of doubts in religion, it is the duty of a true Muslim to trust maulvis blindly on what they say and teach.'

According to a pseudo hafiz and an Imam of local mosque,

'They are poor people (referring to seminary students). I cannot uplift their social status, therefore helping them to uplift their status before Allah by motivating them for Jihad. As a reward of martyrdom in jihad, they will enjoy every luxury in paradise.'

Another student of local seminary reflected his views by saying,

'Maulvi sahib (worthy) opened our eyes and 
helped us to lead on the right path; the path of Jihad. If we die during fighting Jihad, we will rule the hearts of people as Shaheed (martyr), but if we succeed, people will respect us as Ghazi (someone who fought against infidels).'

Referring to the politicization of the religion, a female studying medicine in a local medical college said,

'Every week, I hear Friday sermons through loudspeakers from the mosque of our locality. Since my childhood Imam of our mosque delivers same speech every week, and he sites wrong facts and references from Islamic history.'

Another respondent second the mentioned above view and told,

'Pseudo Maulvis try to build false arguments based on Quranic verses for their gains. Despite knowing that every verse has a context, purpose and a history, they misuse the divine dogmas. Dilemma is that one cannot challenge the credibility of a maulvi sitting on Minbar (pulpit in the mosque where the imam (prayer leader) sits to deliver sermons), as people follow them blindly and are ready to take and give life for them.'

From the above discussion, it is evident that religion is playing in the hands of caretakers of mosques and seminaries, who claim themselves as religious authorities and local masses perceive them as custodian of religion. Only few mosques and seminaries are found with true clerics meeting all the prerequisites of being called maulvi and have in-depth knowledge of religion and Sharia. Most of the clerics sitting in mosques are Hafiz and Qaris. The authority and knowledge of maulvis cannot be challenged in any case in that socialorganization. Religious honchos are promoting extremist mindsets in the students enrolled in local seminaries. Besides promoting extremism, religious clergy also justifies the illegal acts like robbery, looting, and kidnaping through Fatwas.

\section{Education}

Education is another important social institution. It has the function to prepare the succeeding generations to take roles of their preceding generation, along with transmission of societal values (Giddens, Sociology, 2009). Education has two modes: informal and formal. The process of informal education starts with the birth, as the individual grows the process of formal education comes in parallel to informal education (Goldthorpe,
2007) . Informal education is generally referred to type of learning that takes place outside the structured curriculum (Rogoff, Callanan, Gutiérrez, \& Erickson, 2016). In informal education, an individual learns unintentionally through the conversation, the exploration and the enlargement of experience in an informal social setting (Rogoff, The Cultural Nature of Human Development, 2003). On the other hand, in formal education, an individual is taught in a systematic and intentional way: in a formal environment like school, and under the trained supervisors like teachers, and a planned curriculum like textbooks (Hess \& Bear, 2010). Through both informal and formal modes of education, an individual learns about social expectations and sanctions of a society.

Since the ancient times, Multan region is considered as the hub of educational institutions. Today the city has more than fourteen universities (Higher Education Commission, Pakistan, 2018), five medical and dental colleges (Pakistan Medical and Dental Council, 2018) , and fifteen hundred public schools (Punjab Education Assessment Report, 2016) . In addition to public institutions, there are hundreds of private schools and colleges in Multan. There is no current data available revealing the exact number of religious seminaries, however past data shows that there are eleven hundred and eight religious seminaries in Multan (Saleem, 2010). As mentioned in prior section, religious rigidity in the district of Multan is at peak. Religious clergy has the strong influence over lives of people. During field research, the researcher has observed that every family in South Punjab follows the cleric of its respective mosque and seminary. Clerics own a significant social status, and guide people in every aspect of life. Acting against the will of cleric is highly discouraged by the society. Clerics discourage modern education and emphasise on religious education. According to a cleric, who owns a seminary,

'Those people who try to improve their living standards and financial status through modern education are irreligious and avaricious of material world. Their ultimate terminus is hell.'

Another student of same seminary said, 'This life is given by Allah; hence we should dedicate it in the path of religion. We should always keep call of Allah in our minds and devote an appropriate amount of time and energy in performing and practicing religious 
responsibilities. And the best religious responsibility is Jihad.'

Local clerics are also found in promoting hatred and exclusivity in the society. Clerics of both sects do not let go an opportunity to criticise and defame the other sect. Hate speech and abusive language on loudspeakers in mosques is the common practice. In Multan region, there are two major sects of Muslims- Sunni and Shiites. Sunnis are in majority and Shiites in minority. A respondent from Sunni sect shared his viewpoint about Shiites by saying,

'America and Shiites should be killed. Both are infidels.'

While referring towards the height of sectarian schism, a respondent enrolled in local medical college cited his childhood memories and told,

'To prohibit us from interacting with Shiites and joining them in processions on $9^{\text {th }}$ and $10^{\text {th }}$ of Maharam (death anniversary of grandson of prophet Muhammad (PBUH)), our maulvi used to tell lie that Shiites are dirty people and add their pee in the food they distribute during processions.'

Another respondent, a practicing lawyer, belonged to Shiite sect shared his experience and said,

II went to attend the funeral prayer of my Sunni friend but their maulvi verboten us (Shiites) to attend the prayer by calling us infidels.'

Another interviewee who was an engineer by profession and a follower of Sunni sect, while pointing out the practice of mourning among Shiites said,

'My maulvi considers Matam (mourning in the memory of the martyrs of Karbala) as Bidah (innovation in religious matters), therefore I hate Shiites.'

Due to rising sectarian rift in the air of Multan region, Shiites residing in the region have developed a sense of insecurity. A Shiite respondent said,

'Just like Sunnis, we believe in one God, the last prophet (PBUH), the holy Quran, and the day of judgement but still they (Sunnis) consider us irreligious and have thirst of our blood.'

Multan region is rich in cultural diversity. In addition to Muslims, the city is home to non-Muslim communities including Hindus, Sikhs and Christians. Minorities are forced to embrace Islam. They are refused to admit in public schools. Their lands are grabbed, and they are accused of false allegations (Gishkori, 2012). The researcher observed that non-Muslim communities residing in Multan are facing critical situations. A respondent, who is a practicing doctor and follower of Hindu religion said,

'Constitution of Pakistan gives us religious freedom, but unfortunately the freedom is confined to papers only.'

Another Hindu businessman seconded the above statement and said,

'We cannot celebrate Holi (festival of colours) openly.'

Just like Hindus, Christians also have grievances against the Muslim community. A father of a local church said, 'We hesitate to celebrate Christmas publicly, and feel scared in wishing each other "Merry Christmas"'

A Muslim student studying in a local college while giving the justification of his hatred against Christians said, 'Merry Christmas means God begotten a son, this phrase clearly contradicts with words of Quran, "God is father to none," therefore they are infidels and should be killed.'

A Muslim student enrolled in local university seconds the above-mentioned concerns of non-Muslim minorities and told,

'We had a Hindu classmate in eighth standard. She was highly inspired with the teachings of a Muslim scholar promoting peace and harmony and used to listen to his sermons without the consent of her family. She wanted to embrace Islam. One day our Quran teacher castigated us for drinking water from her bottle by saying "drinking water from the utensils of infidels is forbidden." After that day, she started saying that there is dichotomy in the words and practices of Muslim. A phrase of hatred transformed her entire perception about Muslims.'

One more respondent, a journalist working in a local newspaper told,

'Many times, non-Muslims are accused of false allegations of blasphemy. Allegation of blasphemy is used as tool to grab lands and properties of non-Muslim.'

Above and beyond the presence of intense traces of hatred, prejudice, annoyance and grievance in the atmosphere of Multan, the researcher found few religious seminaries in the city that are trying to bridge the sectarian schism in the city. Some seminaries in 
Multan are inclusive in nature, and individuals from all Muslim sects are studying there in all peace and harmony. Similarly, some Muslim maulvis, Hindu pandits and Christian priests are observed very dedicated in promoting interfaith harmony. They all together arrange marches and rallies to encourage and indorse love and peace between Muslim and non-Muslim communities of Multan. One respondent, who owned a seminary said,

'Islam teaches us inter-faith harmony and social solidarity; therefore, Muslims majority societies have the religious as well as social obligation to accommodate non-Muslim minorities with all their hearts.'

Formal education system has the purpose to help individuals to unlearn undesirable behaviours that was learned unintentionally through informal ways, and to relearn the desired behaviours according to the societal expectations. A respondent working in a local public school mentioned the failed role of modern education system in bringing about inclusiveness in the society and told that though political and sectarian debates are not allowed in classrooms, yet children build their sectarian opinions from family and environment, she further added,

'A child is taught about his sectarian identity and teachings before the years of enrolment in school, and that learning go in parallel and further strengthens with school education. Religious debates are not allowed in school, then how can a teacher bring the inclusivity in the minds of students?'

Another teacher criticised the flawed education system and said,

'Quranic chapter of Anfal (war booty) is exempted from the course of Islamic Studies because people were of the opinion that the chapter was contributing to promoting extremist mindset. The fault was not in the chapter but unskilled teachers. Teachers failed to teach students about just war doctrine, human rights in warzones and defensive nature of war mentioned in that chapter. Teachers only focus on cramming and grades, whereas actual purpose of education is ignored badly.'

One more respondent while highlighting the role of teacher said that a teacher can never reach up to the social status of a cleric, therefore cannot undo the thoughts and behaviours of individuals constructed by the teacher. She further added,

'Challenging the teachings and ideology of a cleric means calling a serious trouble for yourself.'

From the above-mentioned discussion, it is concluded that modern education system under the government remained unsuccessful to help individuals to unlearn informally learned behaviour. Social status of religious clergy cannot be challenged anyway, therefore their teachings are considered absolute knowledge. In sum, informal mode of education in South Punjab is more powerful medium to construct social behaviour as compared to the formal mode.

\section{Economy}

Economy is another prime social institution that has the function to produce and distribute goods and services in a society (Giddens, Introduction to Sociology, 1991). If a society fails to deliver its masses with just distribution of goods and services, inflation and poverty occurs. South Punjab is an undeveloped and under privileged part of Punjab province. During the field research the researcher observed that the society is divided into two extremes: extreme rich families and extreme poor families. Wadera culture (feudalism) is the common culture of the region, and most families live under the guardianship of waderas (feudal) and work for them, and in exchange of their services, waderas provide them shelter and food. The families living under the wadera are called raiyats (peasants). Raiyat is under the guardianship of same wadera family for centuries and work for them without wages. Waderas mal-treat their raiyat, and their living standards are below the poverty line. In South Punjab, size of family is extensively big because birth control and family planning are perceived un-Islamic as people think that God has taken the responsibility to feed every individual (Sadiqa, 2013). Hence, most of the families have admitted their children in seminaries due to poverty. Religious seminaries in South Punjab are providing free boarding and lodging to the students, and some are also giving monthly stipend. An interviewee, who is a farmer and looks after the lands of a wadera said,

I had nothing to feed my family that's why I sent my sons to seminary.'

Another respondent, working as a housekeeper and also a widow said that her husband died in an accident, and after the death of her husband, her in-laws threw her out 
of their home and her parents refused to keep her son. She wanted him to study but consequent to monetary hardships, she admitted her son in a seminary. She said,

'He is alive and fine because of maulvi sahib

(worthy) and his seminary.'

About a hundred years ago, George Bernard Shaw said, 'the greatest of evils and the worst of crimes is poverty,' and the phase bears a startling relevance to poverty of South Punjab (Dawn, 2010). A respondent, who was a barrister told that his friend was from a poor family. Despite of financial hardships, he somehow managed to complete M.Phil. in Economics. He tried very hard to get job but failed. Due to corruption and nepotism, it is almost impossible for a person to acquire job without reference and bribe. His family had a lot of expectations from him that was why he ended up joining militants. He further added,

'When a society deprives people of their basic rights, they become criminals, militants and terrorists.'

Social and political fault lines are exploited in the hands of non-state actors, for example, in Swat, young children were paid fifty rupees (fifty cents) per day by the Tehreek-e-Taliban Pakistan to spy their families (Iqbal \& Silva, 2013). According to respondents, local militant groups periodically give money to the families of their hired recruits. A respondent working as a prayer leader in local mosque told,

'My father was a peasant of a feudal. Consequent to poverty, he sent me to the seminary. I came in this seminary in torn clothes and empty stomach. This seminary provided me with shelter, food and respect that my parents failed to provide. I served in Afghanistan with Mujahideen (those who engaged in jihad) during Soviet-Afghan war .'

He further said,

'Mujahideen not only give you material benefits but also guide you the path towards paradise; the path of jihad.'

From the above discussion it is concluded that poverty is the prime reason for people to opt education in religious seminaries, and due to lack of modern education and opportunities they end up in acquiring membership with criminal gangs and militant groups.

\section{Government}

Besides family, religion, education, and economics, government is another prime social institution that has the purpose of legislation and implementation of law and order in the society (Giddens, Introduction to Sociology, 1991). Good system of governance is paramount for stable social order. South Punjab makes forty-eight percent of the Punjab's total area. Out of ninety-one million population of the Punjab, twenty-nine million live in South Punjab. National Assembly of Pakistan has one hundred and seventy-four members from Punjab, and thirty-nine of them are from South Punjab. Similarly, provincial assemble has two hundred and ninety-seven members, and eighty of them are from South Punjab (Nizami M. , 2019) . Despite of observable political representation in the parliament and provincial assembly, the region of South Punjab is victim of poor governance. Although Waderas and pirs do not deliver in the region yet are elected as political representatives because of their social status. An interviewee who was a software engineer said,

'Despite knowing that these waderas would not do anything for the betterment of the region, I voted for them under the family pressure.'

Another respondent second the above opinion and said it is impossible to replace wadera and pir culture. Wadera has social supremacy, whereas pir has emotional control over people. He added:

'My mother forced me to vote for the pir by saying

that you were born as a result of invocation of our pir, so be obedient before him.'

Local politicians pay no heed to the development and prosperity of the region. Along with religious politicization, and economic scarcity, bad governance is also responsible for promoting militancy in South Punjab (Khalid \& leghari, 2014). Just like social fault lines, political fault lines are manipulated by non-state actors. Non-state actors use various tactics to gain popular support, for example in 2005, Tehreek-eTaliban killed more than two dozen criminals in North Waziristan region and kept their bodies hung for weeks on the crossroads (Hussain Z. , 2006). The purpose of action was to indorse the local population that Tahreeke-Taliban has the potential to maintain law and order, and social justice. Same is observed by the researcher in South Punjab; militants are engaged in various social services to seek popular support of the local population. A respondent, who works in a brick kiln told that his home and cattle were sink in the way of flood, he was homeless, and no one came to help him at the time of need. He further explained, 
'During floods, when local politicians were offering only lip services, Mujahideen were giving us food and money.'

Militant groups also arrange marriage ceremonies of the daughters of poor people and give them dowry that is a social essential to marry a girl in South Punjab. A respondent who was a poor farmer told that each year Mujahideen organise more than a hundred marriages of poor girls and give them dowry as well. He added,

'Today if my daughter is happily married, it is because of Mujahideen.'

Due to social engagements of militants, people have soft corners for them. One of the respondents, who is a schoolteacher, said,

'I will vote for religious organisations because they will implement Sharia and deliver our rights.'

In the light of above discussion, it is deduced that bad governance is one of the core reasons of militancy in South Punjab. The failure of government to provide the local population with their constitutional rights is leading the population towards militancy in South Punjab.

\section{CONCLUSION}

Efficient functioning of social institutions is essential for the stable society. Societal instability occurs if a social institution mal-function or dominate the role of other social institutions. In South Punjab prime social institutions: religion, education, economy and government are mal-functioning and remained unsuccessful to deliver their purpose and function. Moreover, religion has dominated the institutions of education, economy and government due to which these institutions became paralysed to contribute their roles. When an individual socialises within the mal-functioning and paralysed social institutions, as mentioned in the section of analysis and finding, he develops perceptions and behaviours that are troublesome for the society at large. Militancy in South Punjab is a social product of mal-functioning and paralysed social institutions. To cultivate fruit of peace, it is paramount important to bring about constructive transformation in the structures (social-institutions) of the society. Otherwise, it is impossible to eradicate militancy from South Punjab.

\section{REFERENCES}

Edwards \& Holland. (2013). What is Qualitative
Interviewing. Bloomsbury.

Abbas, H. (2009, April). Defining the Punjabi Taliban Network. CTC Sentinel.

Awan, J. (2016, April 07). South Punjab operation: List of terrorists' facilitators being made. The Nation.

BBC. (2006, September 01). Retrieved from Death sentence for Multan bombing: http://news.bbc.co.uk/2/hi/south_asia/5306402. stm

Bin Perwaiz, S. (2008, August 25). TTP financiers held in Karachi. The New, p. 2.

Boyce\& Neale. (2006). CONDUCTING IN-DEPTH INTERVIEW: A Guide for Designing and Conducting In-depth Interviews for Evaluation Input. Pathfinder International.

Braun, V., \& Victoria, C. (2006). Using thematic analysis in psychology. Qualitative Research in Psychology, 77-101.

(1891). Calcutta Review: Volume 92-93. Calcutta: University of Calcutta.

City District Government, Multan . (2018, June 17). Retrieved from City District Government, Multan : http://www.multan.gov.pk/page.php?data $=44$

Currie, P. M. (2006). The Shrine and Cult of Muinal din Chishti of Ajmer. Oxford: Oxford University Press.

Dawn. (2010, August 2). Retrieved from Origins of poverty in south Punjab: https://www.dawn.com/news/967100

Dawn. (2018, March 31). Dawn. Retrieved from Militant threat in Punjab: https://www.dawn.com/news/1398669

Dunya News. (2017, October 05). Retrieved from Two militants killed in encounter with CTD in Multan: http://dunyanews.tv/en/Pakistan/408306-Twomilitants-killed-in-encounter-with-CTD-in-Multan

Emerson, R. M., Fretz, R. I., \& Shaw, L. L. (2001). Participant Observation and Fieldnotes. In P. Atkinson, A. Coffey, S. Delamont, J. Lofland, \& L. Lofland, Handbook of Ethnography (pp. Emerson, R. M., Fretz, R. I., \& Shaw, L. L. (2001). "Participant Observation and Fieldnotes." In Paul Atkinson, Amanda Coffey, Sara Delamont, Jo356-357). Thousand Oaks, CA: Sage Publications.

Gabol, I. (2016, May 19). Dawn. Retrieved from Eight 'Al Qaeda militants' killed in Multan: https://www.dawn.com/news/1259275

Geo News. (2017, September 30). Retrieved from Terror bid foiled in Multan; four 'terrorists' arrested: 
https://www.geo.tv/latest/160528-ctd-arrestsfour-suspected-terrorists-in-gujranwala

Giddens, A. (1991). Introduction to Sociology. Washington, D.C.: Saylor Academy .

Giddens, A. (2009). Sociology. Cambridge: Polity Press.

Gishkori, Z. (2012, September 3). The Express Tribune. Retrieved from Intolerance growing in South Punjab:

Report: https://tribune.com.pk/story/430418/intoleranc e-growing-in-south-punjab-report/

Goldthorpe, J. H. (2007). On Sociology. Stanford: Stanford University Press.

Hess, R. D., \& Bear, R. M. (2010). Early Formal Education: Current Theory, Research, and Practice. New Jersey: Transaction Publishers.

Higher Education Commission, Pakistan. (2018, June 10). Retrieved from List of Universities in Multan : http://www.hec.gov.pk/english/universities/Pag es/University-Ranking.aspx

Hussain, M. F. (2012). The Anatomy of Crime Terror Nexus in Pakistan. ISSRA Papers.

Hussain, Z. (2006, April 20). Newsline Magazine. Retrieved from Terror in Miramshah: http:www.newslinemagazine.com/2006/04/terro r-in-miramshah/

Institutional Review Boaard for Social and Behavioral Science. (2012, April 13). Retrieved from University of Virginia: http://www.virginia.edu/vpr/irb/sbs/resources_ guide_ethn.html

Iqbal, K., \& Silva, S. D. (2013). Terrorist lifecycles: a case study of Tehrik-e-Taliban Pakistan. Journal of Policing, Intelligence and Counter Terrorism, 7286.

John, W. (2010, August 03). Observer Research Foundation. Retrieved from Terror sanctuary emerging in Punjab: https://www.orfonline.org/research/terrorsanctuary-emerging-in-punjab/

Khalid, I., \& leghari, M. E. (2014). Radicalization of Youth in Southern Punjab. A Research Journal of South Asian Studies, 537-551.

Khalti, S. A. (2015, August 21). Sectarian threat looms large in south Punjab. The Friday Times.

Khan, A. N. (1983). Multan: history and architecture. Islamabad: Institute of Islamic History, Culture \& Civilization, Islamic University.

Klasra, M. (2016, August 05). Extremism in South Punjab.
Retrieved from Centreline: http://www.centreline.com.pk/extremism-insouth-punjab-by-mustansar-klasra/

Latif, A. (2009, April 22). Punjabi Taliban Rise in Waziristan. IslamOnline.net.

Mahmood, J. (2017, January 01). Punjab sees success in intelligence-based operations. Retrieved from Pakistan Forward: http://pakistan.asianews.com/en_GB/articles/cnmi_pf/features/2017 /01/17/feature-02

Mehboob, S. (2011). Governance and Militancy in Pakistan's Southern Punjab Region. Center For Strategic and International Studies. Retrieved from https://www.csis.org/analysis/governanceand-militancy-pakistan\%E2\%80\%99s-southernpunjab-region

Newby, G. (2013). A Concise Encyclopedia of Islam. London: Oneworld Publications.

News Media Live. (2016, May 19). Retrieved from AL QAEDA MILITANTS PLANNING ON MULTAN UNIVERSITY KILLED IN RAID: http://www.newsmedialive.com/al-qaedacommander-among-8-killed-multan-raid/

Nizami, K. A. (2007). The Life and Times of Shaikh Nizam ud din Auliya. New Dehli: Oxford University Press.

Nizami, M. (2019, Feburary 21). The Bahawalpur province is easier to create than South Punjab. Geo News.

Pakistan Medical and Dental Council. (2018, June 24). Retrieved from List of Medical and Dental Colleges http://www.pmdc.org.pk/aboutus/recognizedme dicaldentalcolleges/tabid/109/default.aspx

Pakistan Observer. (2017, December 23). Retrieved from Christmas terror plot foiled; 3 held: https://pakobserver.net/christmas-terror-plotfoiled-3-held/

Pakistan Today. (2018, March 09). Retrieved from Terrorist held, cache of arms seized in Multan: https://www.pakistantoday.com.pk/2018/03/09 /terrorist-held-cache-of-arms-seized-in-multan/

Pakistan: The Militant Jihadi Challenge. (2009, March 13). Retrieved from International Crisis Group: https://www.crisisgroup.org/asia/southasia/pakistan/pakistan-militant-jihadi-challenge

(2016). Pakistan's Jihadist Heartland: Southern Punjab. Brussels : International Crisis Group.

Parsons, T. (1952). The Social System. London: Tavistock. 
Population of Major Cities Census - 2017. (2018, June 15). Retrieved from Way Back Machine: https://web.archive.org/web/20170829162305/ http://www.pbscensus.gov.pk/sites/default/files /population_of_major_cities_census_2017\%20_0.p df

Primeau, L. A. (2003). Reflections on Self in Qualitative Research: Stories of Family. The American Journal of Occupational Therapy, 9-16.

(2017). Provincial Summary Results of 6th Population and Housing Census-2017. Islamabad: Pakistan Bureau of Statistics.

(2016). Punjab Education Assessment Report. Lahore: Government Of Punjab.

Qarni, 0. (2017, June 16). The Express Tribune. Retrieved from 'Terror attack' foiled in Multan, Rangers kill two 'terrorists' in DG Khan: https://tribune.com.pk/story/1437269/terrorattack-foiled-multan-rangers-kill-two-terroristsdg-khan/

Qarni, 0., \& Ismaeel, T. (2016, September 11). Terror purge: Troops swoop down on terrorists in South Punjab. The Express Tribune.

Radio Pakistan. (2018, June 13). Retrieved from 2 terrorists arrested during operation in Multan: http://www.radio.gov.pk/13-06-2018/2terrorists-arrested-during-operation-in-multan

Rao, H. (2017, February 14). Army chief orders 'grand operation' against terrorists in south Punjab. Daily Pakistan.

RAW \& Afghan Intelligence Agencies involved in terrorist activities in Pakistan: Analysts. (2018, February 16). Retrieved from Radio Pakistan: http://www.radio.gov.pk/16-02-2018/rawafghan-intelligence-agencies-involved-in-effortsto-destabilize-pakistan-analysts

Rogoff, B. (2003). The Cultural Nature of Human Development. London: Oxford University Press.

Rogoff, B., Callanan, M., Gutiérrez, K., \& Erickson, F. (2016). The Organization of Informal Learning. Review of Research in Education, 356-401.

Ryan , P., \& Dundon, T. (2008). Case Research
Interviews: Eliciting Superior Quality Data. International Journal of Case Method Research \& Application , 443-450.

Sadiqa, A. (2013). The New Frontiers: Militancy \& Radicalism in Punjab. Norway: Center for International and Strategic Analysis (SISA).

Saleem, A. (2010, June 02). Punjab's seminary fact-file. The Express Tribune.

Shah, Z. (2008, October 23). Hostage to jihad. Herald, pp. $6-17$.

The Express Tribune. (2017, February 16). Retrieved from 6 TTP-JA militants killed in CTD raid in Multan: https://tribune.com.pk/story/1328860/6-ttp-jamilitants-killed-ctd-raid-multan/

The Nation. (2015, September 16). Retrieved from Terror In Multan: https://nation.com.pk/16-Sep2015/terror-in-multan

The Nation. (2016, october 16). Retrieved from From bright lights to madrassa floors: https://nation.com.pk/16-Oct-2016/from-brightlights-to-madrassa-floors

The Nation. (2018, March 24). Retrieved from Four terrorists held with arms, explosives in Multan: https://nation.com.pk/24-Mar-2018/fourterrorists-held-with-arms-explosives-in-multan

Thornhill, A., E.T. Lewis, P., \& Nk Saun, M. (2007). Research Methods for Business Students. New Jersey : Financial Times/Prentice Hall. Retrieved from https://researchmethodology.net/sampling-in-primary-datacollection/purposive-sampling/

Winterbotham, E. (2016, July 15). The Missing Half of Pakistan's Fight Against Terrorism. The Diplomat.

Yousafzai, R. (2016, April 24). Who are Punjabi Taliban? Retrieved from The News: http://tns.thenews.com.pk/punjabitaliban/\#.WJ9uU_197IU

Zia, S. (2012, May 06). South Punjab: larger in size, less in population. Retrieved from The News: https://nation.com.pk/06-May-2012/southpunjab-larger-in-size-less-in-population 
Publisher's note: EScience Press remains neutral with regard to jurisdictional claims in published maps and institutional affiliations.

(c) ()

Open Access This article is licensed under a Creative Commons Attribution 4.0 International License, which permits use, sharing, adaptation, distribution and reproduction in any medium or format, as long as you give appropriate credit to the original author(s) and the source, provide a link to the Creative Commons license and indicate if changes were made. The images or other third-party material in this article are included in the article's Creative Commons license, unless indicated otherwise in a credit line to the material. If material is not included in the article's Creative Commons license and your intended use is not permitted by statutory regulation or exceeds the permitted use, you will need to obtain permission directly from the copyright holder. To view a copy of this license, visit http://creativecommons.org/licenses/by/4.0/.

(C) The Author(s) 2021. 